\title{
Consumption of diets containing raw soya beans (Glycine max), kidney beans (Phaseolus vulgaris), cowpeas (Vigna unguiculata) or lupin seeds (Lupinus angustifolius) by rats for up to 700 days: effects on body composition and organ weights
}

\author{
BY GEORGE GRANT, PATRICIA M. DORWARD, WENDY C. BUCHAN, \\ JULIA C. ARMOUR AND ARPAD PUSZTAI \\ Rowett Research Institute, Bucksburn, Aberdeen AB2 9SB
}

(Received 18 March 1993 - Revised 5 May 1994 - Accepted 7 June 1994)

\begin{abstract}
Feeding trials have been done with rats to assess the effects of long-term (700 d) consumption of diets based on raw cowpeas (Vigna unguiculata; moderate Bowman-Birk inhibitor content, low lectin content), lupin seeds (Lupinus angustifolius; low lectin and protease inhibitor content) or soya beans (Glycine max; high Kunitz inhibitor content, moderate Bowman-Birk inhibitor content, moderate lectin content) or diets containing low levels of raw kidney bean (Phaseolus vulgaris; high lectin content, low Bowman-Birk inhibitor content) on body weight and composition and organ weights. All the legume-based diets reduced feed conversion efficiency and growth rates during the initial $250 \mathrm{~d}$. However, after $250 \mathrm{~d}$ the weight gains by rats given legume-based diets were similar to those of controls given the same daily feed intake. Long-term consumption of diets containing low levels of kidney bean significantly altered body composition of rats. The levels of lipid in the body were significantly reduced. As a result, carcasses of these rats contained a higher proportion of muscle/protein than did controls. Small-intestine relative weight was increased by short- and long-term consumption of the kidney-bean-based diet. However, the increase in relative pancreatic weight observed at $30 \mathrm{~d}$ did not persist long term. None of the other legume-based diets caused any significant changes in body composition. However, long-term exposure to a soya-bean- or cowpea-based diet induced an extensive increase in the relative and absolute weights of the pancreas and caused an increase in the incidence of macroscopic pancreatic nodules and possibly pancreatic neoplasia. Long-term consumption of the cowpea-, kidney-bean-, lupin-seed- or soya-beanbased diets by rats resulted in a significant increase in the relative weight of the caecum and colon.
\end{abstract}

Legumes: Rat: Body composition: Gastrointestinal tract: Pancreas

Commonly consumed legume seeds, such as kidney beans and soya beans, contain various components which can potentially interfere with the body metabolism of humans or animals (Liener, 1980, 1989). The predominant antinutritional factors in these particular species are the lectins and trypsin inhibitors (Liener, 1980, 1989; Pusztai, 1989, 1991).

Short-term $(10 \mathrm{~d})$ dietary exposure to purified kidney-bean or soya-bean lectin impairs the growth of rats, induces enlargement of the small intestine, causes damage to the epithelium of the small intestine and stimulates hypertrophy and hyperplasia in the pancreas (Grant, 1989; Pusztai et al. 1990; Pusztai, 1991). In addition, at high dietary concentrations kidney-bean lectins induce rapid depletion of body muscle, lipid and glycogen (Pusztai, 1989, 1991).

Dietary protease inhibitors also interfere with intestinal and systemic metabolism. In particular, consumption of purified soya-bean (Kunitz (trypsin) and Bowman-Birk (trypsin/chymotrypsin)) protease inhibitors by rats for $10 \mathrm{~d}$ inhibits their growth, mediates enlargement of the pancreas and induces a slight increase in small-intestine weight (Grant 
et al. 1987a, b; Grant, 1989). Similar although less extensive changes have also been observed in rats fed with purified cowpea (Bowman-Birk type) inhibitor (Pusztai et al. 1992).

The long-term effects of dietary soya bean on pancreatic metabolism in rats have been studied (McGuiness et al. 1984; Gumbmann et al. 1985, 1989; Grant et al. 1989, 1993). However, little is known about the consequences for general body metabolism of long-term dietary exposure to dietary lectins and protease inhibitors. Therefore, four legume seeds of differing lectin and trypsin inhibitor contents were tested in rats over a $700 \mathrm{~d}$ period for their dietary effects on body metabolism. The seeds used were: cowpea (Vigna unguiculata), kidney bean (Phaseolus vulgaris), lupin seed (Lupinus angustifolius) and soya bean (Glycine $\max )$.

\section{MATERIALS AND METHODS}

Raw kidney beans (var. Processor) were purchased from Booker Seeds (Sleaford, Lincs.) and raw soya beans and raw cowpeas from Real Foods (Edinburgh). Raw lupin seeds were received from the Grain Pool of Western Australia. All seeds were ground in a Glen Creston Hammermill (Glen Creston, Stanmore, Herts.) fitted with $1 \mathrm{~mm}$ mesh. Maize oil was bought from Strachan and Sons (Aberdeen) and lactalbumin and all other dietary materials and reagents from BDH (Poole, Dorset) or the Sigma Chemical Co. (Poole, Dorset).

Estimations of protease-inhibitor content were done essentially as described previously (Grant et al. 1986). Seed meals were initially defatted by extraction with light (b.p. $40-60^{\circ}$ ) petroleum $(1: 20, \mathrm{w} / \mathrm{v})$ at room temperature overnight. The defatted meal was air-dried at room temperature, extracted by stirring with $0.2 \mathrm{M}$-citrate-phosphate buffer $\mathrm{pH} 7 \cdot 0(1: 10$, $\mathrm{w} / \mathrm{v}$ ) overnight at $+1^{\circ}$, centrifuged at $50000 \mathrm{~g}$ for $20 \mathrm{~min}$ and the supernatant decanted. Commercial trypsin (EC 3.4.21.4; type III from bovine pancreas) or chymotrypsin (EC 3.4.21.1; type 1-S from bovine pancreas), in which the true enzyme content was estimated by active site titration using $p$-nitrophenyl- $\boldsymbol{p}^{\prime}$-guanidinobenzoate and $N$-transcinnamoylimidazole respectively (Schonbaum et al. 1961; Chase \& Shaw, 1976), was added in excess to the seed extracts and the mixtures were left on ice to react. The level of uninhibited trypsin activity in the reaction mixture was assessed using $N \alpha$-benzoyl-DLarginine-p-nitroanilide as substrate (Kakade et al. 1969) and the level of uninhibited chymotrypsin was evaluated using glutaryl-1-phenylalanine-p-nitroanilide as substrate (Erlanger et al. 1964). Trypsin and chymotrypsin inhibitory activity was expressed as $\mathrm{g}$ enzyme inhibited $/ \mathrm{kg}$ original raw meal and the protease-inhibitor contents of the test diets calculated on the basis of the level of raw seed meal inclusion in the diet.

Haemagglutinating activity in the $\mathrm{pH} 7.0$ buffer extracts was estimated by a serial dilution procedure using trypsin-treated rat blood cells (Grant et al. 1986; Grant 1991). One unit of haemagglutinating activity (HU) was defined as that being present in the amount of material in the last dilution giving $50 \%$ agglutination of the blood cells. The specific activities $(\mathrm{HU} / \mathrm{kg})$ of the original seed meals were calculated. As with the protease inhibitors, the lectin content in the test diets was expressed on the basis of the level of raw seed meal inclusion in the diet.

Soya-bean meal, as expected, had a high protease-inhibitor content (24.6 (SD 1.5) g trypsin inhibited $/ \mathrm{kg}, 12.0$ (SD 1.8) g chymotrypsin inhibited $/ \mathrm{kg}$ ). In contrast, cowpea meal and kidney-bean meal contained moderate concentrations of protease inhibitors $(8.0$ (SD 0.8) $\mathrm{g}$ trypsin inhibited $/ \mathrm{kg}, 9.1$ (SD 0.9) $\mathrm{g}$ chymotrypsin inhibited $/ \mathrm{kg}$ and 10.6 (SD 1.5) $\mathrm{g}$ trypsin inhibited $/ \mathrm{kg}, 9 \cdot 2$ (SD 1.1) g chymotrypsin inhibited $/ \mathrm{kg}$ respectively). In addition, lupin-seed meal was found to contain only small amounts of protease inhibitors $(1.1(\mathrm{SD} 0.8) \mathrm{g}$ trypsin inhibited $/ \mathrm{kg}, 1.4(\mathrm{SD} 0.8) \mathrm{g}$ chymotrypsin inhibited $/ \mathrm{kg})$. 
Table 1. Composition of experimental diets $(\mathrm{g} / \mathrm{kg})$

\begin{tabular}{|c|c|c|c|c|c|c|}
\hline Diet... & CONTROL & LUPIN & $30 \mathrm{~KB}$ & $90 \mathrm{~KB}$ & SOY & COWPEA \\
\hline Soya bean (Glycine max) & - & - & - & - & 274 & - \\
\hline Cowpea (Vigna unguiculata) & - & - & - & - & - & 380 \\
\hline Lupin seed (Lupinus angustifolius) & - & 320 & - & - & - & - \\
\hline Kidney bean (Phaseolus vulgaris) & - & - & 30 & 90 & - & - \\
\hline Lactalbumin & 126 & - & 118 & 105 & - & - \\
\hline Maize starch & 244 & 70 & 224 & 180 & 166 & 10 \\
\hline Potato starch & 100 & 100 & 100 & 100 & 100 & 100 \\
\hline Glucose & 210 & 210 & 210 & 210 & 210 & 210 \\
\hline Maize oil & 220 & 200 & 218 & 215 & 150 & 200 \\
\hline Vitamins & 50 & 50 & 50 & 50 & 50 & 50 \\
\hline Minerals & 50 & 50 & 50 & 50 & 50 & 50 \\
\hline L-Tryptophan & - & 0.50 & 0.03 & $0 \cdot 10$ & 0.36 & 0.50 \\
\hline L-Methionine & - & 2.00 & 0.20 & 0.60 & $2 \cdot 42$ & $3 \cdot 00$ \\
\hline Silicic acid & 0.40 & 0.40 & 0.40 & 0.40 & $0 \cdot 40$ & 0.40 \\
\hline \multicolumn{7}{|c|}{ Protease inhibitor (g enzyme inhibited $/ \mathrm{kg}$ diet) } \\
\hline Trypsin inhibited (g) & $0 \cdot 00$ & 0.35 & 0.32 & 0.93 & 6.74 & 3.05 \\
\hline Chymotrypsin inhibited (g) & 0.00 & 0.45 & 0.29 & 0.81 & $3 \cdot 29$ & 3.45 \\
\hline \multirow{2}{*}{\multicolumn{7}{|c|}{ Lectin (haemagglutinating (HU) $/ \mathrm{kg}$ diet) }} \\
\hline & $0 \cdot 0$ & $0 \cdot 1$ & $2 \cdot 5$ & 7.6 & $1 \cdot 4$ & $0 \cdot 1$ \\
\hline
\end{tabular}

Kidney-bean meal contained high levels of lectin ( 840 (SD 300$) \mathrm{HU} \times 10^{-5} / \mathrm{kg}$ ). In contrast, soya-bean meal contained only moderate amounts of lectin (50 (SD 10) HU $\times$ $10^{-5} / \mathrm{kg}$ ) whilst cowpea and lupin-seed meals contained only small amounts ( 3 (SD 1$) \mathrm{HU} \times$ $10^{-5} / \mathrm{kg}$ for both).

On the basis of these findings, diets containing $100 \mathrm{~g}$ total protein and $220 \mathrm{~g} \mathrm{lipid} / \mathrm{kg}$ and with a gross energy content of $19 \cdot 3 \mathrm{MJ} / \mathrm{kg}$ in which cowpea, lupin seed or soya bean provided the sole source of dietary protein (Table 1) were formulated as before (Grant et al. 1986). Kidney bean was incorporated into a predominantly lactalbumin-based diet at a concentration $(30 \mathrm{~g} / \mathrm{kg}$ ) which would give a dietary lectin content approximating that in the soya-bean diet. However, unlike the soya-bean diet this diet would contain only low levels of protease inhibitors. A second kidney-bean diet was formulated $(90 \mathrm{~g} / \mathrm{kg})$ to give a diet with a relatively high lectin content. Both these kidney-bean diets contained $100 \mathrm{~g}$ total protein $/ \mathrm{kg}$.

Mixed diets were stored at $-20^{\circ}$ and were fed to the rats over a 3-4-week period. Fresh diets were prepared every $3-4$ weeks. The cowpeas, kidney beans, lupin seeds and soya beans used throughout were from single batches of these seeds purchased before commencement of the present study. All the other components in the semi-purified diets were of chemically defined composition.

Male Hooded-Lister (Rowett strain) rats, reared and housed in the breeding/ experimental small-animal unit of the Rowett Research Institute were used in these studies. They were weaned at $19 \mathrm{~d}$, fed on non-purified stock diet (Labsure, Manea, Cambs.) for $10 \mathrm{~d}$ and then fed on semi-purified control diet (Table 1) for 5-6 d. Subsequently, after the rats had reached $100-105 \mathrm{~g}$ in weight they were given the appropriate test or control diets exclusively. Water was freely available at all times.

A total of 292 rats were used in five separate feeding trials. In the first trial, in which rats were given either soya-bean-based (SOY) or lactalbumin-based (CONTROL) diets, the test rats were given free access to the SOY diet. Control rats were strictly pair-fed to the daily 
intake of the SOY-fed rats. Initially food intakes of the rats were 7 (SD 2) g/rat per d. They increased progressively over the next 15 weeks to 17 (SD 2) g/rat per d and remained at this level until the end of the experiment. The initial feed intakes were approximately $60 \%$ of that consumed by rats given free access to the control diet but were still well above that necessary to meet the minimum energy, mineral and vitamin requirements of the rats. From 15 weeks onwards, feed intakes were similar to those of rats given free access to the control diet. The rats were weighed every $3-4 \mathrm{~d}$.

In subsequent rat feeding trials the amount of feed offered daily to all rats was made equal to the average daily intake of the rats given SOY diet at the same stage in the initial trial. All feed offered was consumed by the rats.

In trials 1 and 2 a total of thirty-five rats (fifteen in trial 1 and twenty in trial 2) were fed on the SOY diet and thirty-five (fifteen in trial 1 and twenty in trial 2) were fed on the CONTROL diet for up to $700 \mathrm{~d}$. With the exception of eight SOY-fed rats and three CONTROL rats which had to be killed earlier because they were showing signs of distress, all the remainder were killed at $700 \mathrm{~d}$.

In trials 3, 4 and 5 a total of thirty-nine rats were fed on CONTROL diet, thirty-nine rats were fed on the cowpea-based (COWPEA) diet, thirty-nine on the $30 \mathrm{~g} / \mathrm{kg}$ kidney-beanbased $(30 \mathrm{~KB})$ diet, thirty-nine on the $90 \mathrm{~g} / \mathrm{kg}$ kidney-bean-based $(90 \mathrm{~KB})$ diet, twentyseven on the lupin-seed-based (LUPIN) diet and thirty-nine on the SOY diet. In trial 3 twelve rats were allocated to each of the dietary treatments except LUPIN which was not included. In trial 4 twelve rats were allocated to each of the dietary treatments and in trial 5 fifteen rats were allocated to each treatment. In each of the trials a proportion of the test and control rats was killed at 30,250 and $700 \mathrm{~d}$. All the rats were killed at pre-planned timepoints during the trials with the exception of four SOY-fed rats, one COWPEA-fed rat and one CONTROL rat which had to be killed between 500 and $700 \mathrm{~d}$ because they were showing signs of distress.

Control- and SOY-fed groups of rats were included in each of the five feeding trials. The $30 \mathrm{~KB}$, COWPEA and LUPIN diets were included in trials 3-5. Cross-comparison of the individual weight gain, body composition and tissue weight data obtained in each trial indicated that there were no significant inter-trial variations in the responses of rats to the diets.

The rats were killed at either 30,250 or $700 \mathrm{~d}$ by anaesthetic overdose followed by exsanguination. Feed had been removed overnight, the rats were given $5 \mathrm{~g}$ of the appropriate diet the following morning and killed exactly $2 \mathrm{~h}$ later. This procedure was adopted to minimize any effects arising from differences in amount and time of feed intake.

The stomach, small intestine, caecum and colon were removed and their contents washed out with copious amounts of ice-cold 0.05 M-phosphate buffered saline (PBS). The tissues were blotted dry, given a visual examination for the presence of any macroscopic lesions and then frozen on dry ice. The liver, kidneys, adrenals, pancreas, spleen, thymus, lungs, heart, thyroid and the soleus, plantaris and gastrocnemius hind-limb muscles were excised, washed with PBS, blotted dry, examined and frozen on dry ice. All the tissues and remaining carcass were weighed, freeze-dried and reweighed. To minimize differences due to rat weight and water content, all tissue weights were expressed as g dry weight/kg dry body weight.

The remaining carcass and organs and tissues were recombined and ground with a mincer. Totai carcass $\mathrm{N}$ content was estimated by a macrokjeldahl method (Davidson et al. 1970 ) and body protein was calculated as $\mathrm{N} \times 6-25$. Estimation of total lipid was done by extraction of the ground tissue with chloroform-methanol $(2: 1, \mathrm{v} / \mathrm{v})$ at a sample: solvent ratio of $1: 200$, w/v (Grant et al. 1986).

Results were expressed as arithmetic means with a pooled standard deviation. One-way 
ANOVA was carried out on the data using the Minitab statistical software package (Minitab, New York, NY, USA) and multiple comparisons were done by the Tukey test (Zar, 1984). Differences were considered to be significant if $P \leqslant 0 \cdot 01$.

\section{RESULTS}

All rats, irrespective of whether they were fed on the control or the test diets, gained weight throughout the 700-d experimental period (Tables 2 and 3). However, there were considerable differences in the efficiency with which the rats utilized the various diets (Fig. 1). Thus, rats fed on the SOY or $90 \mathrm{~KB}$ diets utilized the diet less efficiently and gained weight far more slowly than did the controls. As a result, by $250 \mathrm{~d}$ they were on average 130-150 g lighter than comparable control rats (Tables 2 and 3).

Weight gains were also reduced in rats fed on COWPEA, LUPIN or $30 \mathrm{~KB}$ diets (Fig. 1). However, the impairment was less than that caused by the SOY or $90 \mathrm{~KB}$ diets. Thus, at $250 \mathrm{~d}$, rats fed on COWPEA, LUPIN or $30 \mathrm{~KB}$ diets were only $60-70 \mathrm{~g}$ lighter than the control rats (Table 3 ).

Efficiency of feed conversion decreased steadily with time, and from 200-700 d the values obtained for the test diets were not significantly different from those for the control diet (Fig. 1). All the rats therefore gained weight at approximately the same rate during this period. Thus, the net differences in weight between the control and test rats observed at $250 \mathrm{~d}$ were essentially maintained during the remainder of the experiment.

Lipid deposition was greatly reduced in rats fed on the $90 \mathrm{~KB}$ diet for 30,250 or $700 \mathrm{~d}$. Despite having feed and lipid intakes similar to those of controls, the carcasses of rats fed on $90 \mathrm{~KB}$ contained approximately $13 \mathrm{~g}$ lipid at $30 \mathrm{~d}, 85 \mathrm{~g}$ at $250 \mathrm{~d}$, and $183 \mathrm{~g}$ at $700 \mathrm{~d}$, whereas comparable controls contained approximately 24,173 and 307 g respectively. As a result, the proportion of lipid in the carcass of these rats was considerably decreased at all three timepoints (Table 3).

Protein deposition was also adversely affected by feeding the rats on the $90 \mathrm{~KB}$ diet. The carcasses of rats fed on $90 \mathrm{~KB}$ contained approximately $29 \mathrm{~g}$ protein at $30 \mathrm{~d}, 72 \mathrm{~g}$ at $250 \mathrm{~d}$ and $82 \mathrm{~g}$ at $700 \mathrm{~d}$, whereas comparable controls contained approximately 40,90 and $99 \mathrm{~g}$ respectively. Therefore, unlike the effects on lipid deposition which seemed to occur throughout the whole 700-d period, the interference with protein accretion appeared to be most extensive during the initial rapid growth phase of the rats. The impairment of protein accretion was, however, much less extensive than that of lipid accretion at all time points. Thus, the proportion of protein in the carcass of rats fed on $90 \mathrm{~KB}$ was considerably higher than that in comparable controls at 30,250 or $700 \mathrm{~d}$ (Table 3). Carcasses of rats fed on the $90 \mathrm{~KB}$ diet contained a higher proportion of water than did carcasses of control rats (Table

3). As a result, the water:protein ratio for these rats was higher than that for control rats.

Consumption of the $30 \mathrm{~KB}$, COWPEA, LUPIN or SOY diets did reduce net protein and lipid accretion. However, unlike the findings with $90 \mathrm{~KB}$ diet, consumption of these diets did not result in any alterations to the proportions of lipid and protein in the carcass (Tables 2 and 3).

Consumption of the SOY diet by rats for 30,250 or $700 \mathrm{~d}$ led to significant changes in the relative weights (g/kg dry body weight) of some tissues (Tables 2 and 4). In particular, very extensive enlargement of the pancreas was evident in all rats fed on this diet for 30 , 250 or $700 \mathrm{~d}$. Furthermore, in a proportion of the pancreas samples taken from rats fed on SOY for $700 \mathrm{~d}$ some development of macroscopic pancreatic nodules was evident. These lesions were not evident at earlier timepoints and were not observed in any of the control rats. No other tissues were significantly altered in rats given SOY for $30 \mathrm{~d}$. However, the stomach, caecum and colon were enlarged in rats given SOY for 250 or $700 \mathrm{~d}$ (Tables 2 and 4). 
Table 2. Body weights ( $B W$ ), carcass composition and dry tissue weights from rats fed on a control diet or a diet containing soya bean (SOY) for $700 d^{*}$

\begin{tabular}{lccc}
\hline \multicolumn{1}{c}{ Diet... } & $\begin{array}{c}\text { CONTROL } \\
(n \text { 32) }\end{array}$ & $\begin{array}{c}\text { SOY } \\
(n \text { 27) }\end{array}$ & $\begin{array}{c}\text { Pooled } \\
\text { SD }\end{array}$ \\
\hline Fresh BW (g) & $777^{\mathrm{a}}$ & $600^{\mathrm{b}}$ & 32 \\
Water (g/kg fresh BW) & $405^{\mathrm{a}}$ & $444^{\mathrm{a}}$ & 33 \\
Dry BW (g) & $462^{\mathrm{a}}$ & $334^{\mathrm{b}}$ & 21 \\
Protein (g/kg dry BW) & $228^{\mathrm{a}}$ & $239^{\mathrm{a}}$ & 22 \\
Lipid (g/kg dry BW) & $680^{\mathrm{a}}$ & $670^{\mathrm{a}}$ & 22 \\
Stomach (g/kg dry BW) & $1 \cdot 4^{\mathrm{a}}$ & $2 \cdot 4^{\mathrm{b}}$ & $0 \cdot 4$ \\
Small intestine (g/kg dry BW) & $9 \cdot 9^{\mathrm{a}}$ & $10 \cdot 4^{\mathrm{a}}$ & $0 \cdot 9$ \\
Caecum (g/kg dry BW) & $0 \cdot 9^{\mathrm{a}}$ & $1 \cdot 6^{\mathrm{b}}$ & $0 \cdot 3$ \\
Colon (g/kg dry BW) & $1 \cdot 2^{\mathrm{a}}$ & $2 \cdot 2^{\mathrm{b}}$ & $0 \cdot 3$ \\
Pancreas (g/kg dry BW) & $1 \cdot 0^{\mathrm{a}}$ & $2 \cdot 4^{\mathrm{b}} \ddagger$ & $0 \cdot 2$ \\
Gastrocnemius muscles (g/kg dry BW) $\dagger$ & $3 \cdot 0^{\mathrm{a}}$ & $3 \cdot 0^{\mathrm{a}}$ & $0 \cdot 3$ \\
\hline
\end{tabular}

a,b Values within a row with unlike superscript letters were significantly different $(P \leqslant 0.01)$.

* For details of diets and procedures, see Table 1 and pp. 18-20.

$\dagger$ Combined weight of muscles from both hind legs.

$\ddagger$ Limited development of macroscopic pancreatic nodules was evident in ten of the SOY group of rats. These lesions were not apparent in the remainder of these rats or in the control group.

Table 3. Body weights (BW) and composition of rats fed for 30,250 or $700 \mathrm{~d}$ on control diet or diets containing legume-seed meals*

(Mean values for the following numbers of animals: $30 \mathrm{~d}, n 12 ; 250 \mathrm{~d}, n 12 ; 700 \mathrm{~d}, n 15$ except for SOY $(n$ 11), COWPEA $(n 14)$ and CONTROL $(n 14))$

\begin{tabular}{|c|c|c|c|c|c|c|c|}
\hline Diet... & CONTROL & LUPIN & $30 \mathrm{~KB}$ & $90 \mathrm{~KB}$ & SOY & COWPEA & $\begin{array}{c}\text { Pooled } \\
\text { SD }\end{array}$ \\
\hline \multicolumn{8}{|l|}{ Fresh BW (g) } \\
\hline $30 \mathrm{~d}$ & $187^{a}$ & $172^{\mathrm{a}}$ & $173^{\mathrm{a}}$ & $143^{\mathrm{b}}$ & $139^{b}$ & $170^{\mathrm{a}}$ & 12 \\
\hline $250 \mathrm{~d}$ & $610^{\mathrm{a}}$ & $546^{\mathrm{b}}$ & $547^{\circ}$ & $461^{\circ}$ & $466^{c}$ & $541^{b}$ & 27 \\
\hline $700 \mathrm{~d}$ & $760^{\mathrm{a}}$ & $689^{\mathrm{b}}$ & $695^{b}$ & $599^{\circ}$ & $609^{\mathrm{c}}$ & $690^{\mathrm{b}}$ & 31 \\
\hline \multicolumn{8}{|l|}{ Water $(\mathrm{g} / \mathbf{k g}) \dagger$} \\
\hline $30 \mathrm{~d}$ & $620^{\mathrm{a}}$ & ND & $615^{\mathrm{a}}$ & $663^{b}$ & $633^{2}$ & $629^{\mathrm{u}}$ & 17 \\
\hline $250 \mathrm{~d}$ & $520^{\mathrm{a}}$ & $569^{a}$ & $534^{\mathrm{a}}$ & $621^{\mathrm{b}}$ & $575^{\mathrm{a}}$ & $553^{\mathrm{a}}$ & 31 \\
\hline $700 \mathrm{~d}$ & $411^{\mathrm{a}}$ & $455^{\mathrm{a}}$ & $422^{2}$ & $511^{\mathrm{b}}$ & $452^{a}$ & $450^{\mathrm{y}}$ & 27 \\
\hline \multicolumn{8}{|l|}{ Dry BW (g) } \\
\hline $30 \mathrm{~d}$ & $71^{a}$ & ND & $67^{a}$ & $48^{b}$ & $51^{b}$ & $63^{\mathrm{c}}$ & 3 \\
\hline $250 \mathrm{~d}$ & $293^{a}$ & $235^{\mathrm{h}}$ & $255^{\mathrm{b}}$ & $175^{\mathrm{c}}$ & $198^{\circ}$ & $242^{\mathrm{b}}$ & 19 \\
\hline $700 \mathrm{~d}$ & $448^{a}$ & $376^{\mathrm{b}}$ & $402^{b}$ & $293^{\circ}$ & $334^{\circ}$ & $380^{\mathrm{b}}$ & 19 \\
\hline \multicolumn{8}{|l|}{ Protein $(\mathrm{g} / \mathrm{kg}) \ddagger$} \\
\hline $30 \mathrm{~d}$ & $560^{\mathrm{a}}$ & ND & $555^{\mathrm{a}}$ & $611^{\mathrm{b}}$ & $560^{a}$ & $555^{\mathrm{a}}$ & 19 \\
\hline $250 \mathrm{~d}$ & $308^{a}$ & $328^{\mathrm{a}}$ & $333^{a}$ & $403^{b}$ & $343^{a}$ & $321^{\mathrm{a}}$ & 25 \\
\hline $700 \mathrm{~d}$ & $221^{\mathrm{a}}$ & $238^{\mathrm{a}}$ & $235^{\mathrm{a}}$ & $281^{\mathrm{b}}$ & $233^{\mathrm{a}}$ & $229^{a}$ & 19 \\
\hline \multicolumn{8}{|l|}{ Lipid $(\mathrm{g} / \mathrm{kg}) \ddagger$} \\
\hline $30 \mathrm{~d}$ & $333^{a}$ & ND & $338^{\mathrm{a}}$ & $276^{\mathrm{b}}$ & $326^{a}$ & $335^{\mathfrak{a}}$ & 15 \\
\hline $250 \mathrm{~d}$ & $592^{\mathrm{a}}$ & $571^{a}$ & $558^{a}$ & $488^{b}$ & $557^{\mathrm{a}}$ & $576^{\mathrm{a}}$ & 25 \\
\hline $700 \mathrm{~d}$ & $686^{\mathrm{a}}$ & $672^{\mathrm{a}}$ & $675^{\mathrm{a}}$ & $625^{b}$ & $677^{a}$ & $680^{\mathrm{a}}$ & 21 \\
\hline
\end{tabular}

LUPIN, lupin-seed (Lupinus angustifolius) meal; $30 \mathrm{~KB}, 30 \mathrm{~g}$ kidney bean (Phaseolus vulgaris var. Processor) $/ \mathrm{kg}$ diet; $90 \mathrm{~KB}, 90 \mathrm{~g}$ kidney bean $/ \mathrm{kg}$ diet; SOY, soya-bean (Glycine max) meal; COWPEA, cowpea (Vigna unguiculata) meal; ND, not determined.

$\mathbf{a}, \mathbf{b}, \mathbf{e}$ Values within a row with unlike superscript letters were significantly different $(P \leqslant 0.01)$.

* For details of diets and procedures, see Table 1 and pp. 18-20.

$\dagger \mathrm{g} / \mathrm{kg}$ fresh body weight.

$\ddagger \mathrm{g} / \mathrm{kg}$ dry body weight. 

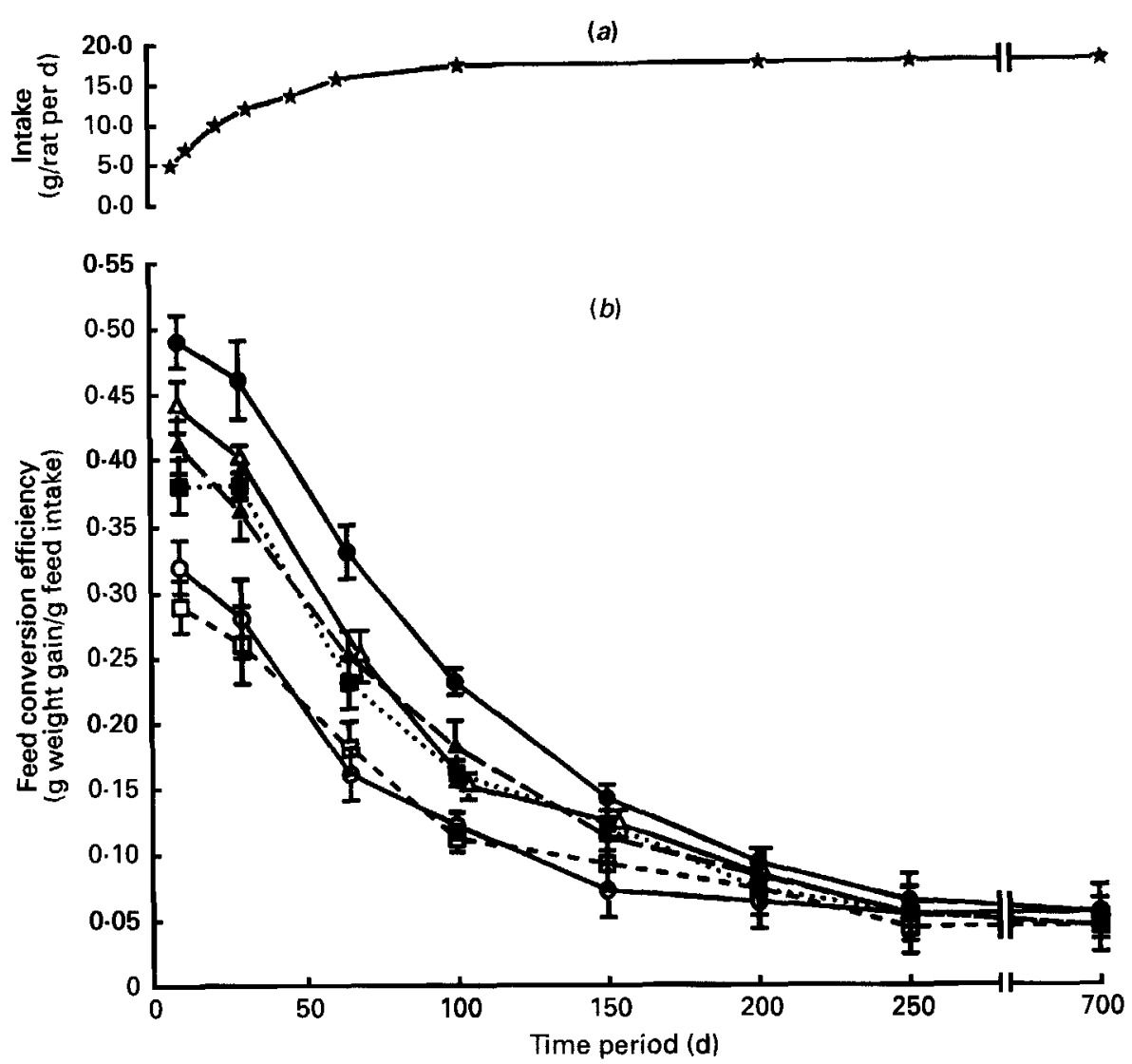

Fig. 1. (a) Feed intake and $(b)$ feed conversion efficiencies for rats fed with equal amounts of a control diet (O) or diets containing cowpea (Vigna unguiculata; $\mathbf{\Delta}$ ), kidney bean (Phaseolus vulgaris var. Processor; $30 \mathrm{~g} / \mathrm{kg}(\triangle)$ ), kidney bean $90 \mathrm{~g} / \mathrm{kg}(\square)$, lupin seed (Lupinus angustifolius; $\square$ ) or soya bean (Glycine max; $O$ ) for up to $700 \mathrm{~d}$. Values are means for twelve or more rats, with their standard errors indicated by vertical bars. Analysis of the data indicated that for timepoints between 10 and $100 \mathrm{~d}$ diets could be ranked: control $>30 \mathrm{~g}$ kidney bean $/ \mathrm{kg}$ $=$ lupin seed $=$ cowpea $>90 \mathrm{~g}$ kidney bean $/ \mathrm{kg}=$ soya bean $(P \leqslant 0 \cdot 01)$. From $200-700 \mathrm{~d}$ there were no significant differences between diets.

Pancreatic growth was even more extensive in the twelve SOY-fed rats which had to be killed between 500 and $700 \mathrm{~d}$ (Table 5). Pancreas weights were at least 2-3 times greater than those found in the majority of rats fed on SOY for $700 \mathrm{~d}$ and at least 4-7 times greater than those in controls. In addition, macroscopic pancreatic nodules were present over the whole surface of pancreata from all these rats. The appearance of the tissue and the presence of adhesions to other tissues suggested that pancreatic neoplasia may have occurred in four of these rats. With eight of the rats the weights of other body tissues were similar to those measured in the majority of SOY-fed rats. However, in the four rats which appeared to show signs of neoplasia the spleen was found to have been increased 3-fold in weight, the liver and kidneys were also significantly heavier, whilst the weights of the gastrocnemius muscles, small intestine, caecum and colon were significantly reduced (Table 5).

There were considerable similarities between the changes in rat tissue weights caused by the SOY diet and those induced by the COWPEA diet (Tables 4 and 5). However, whilst the increases in the weights of the stomach, caecum and colon caused by dietary COWPEA 
Table 4. Dry weights ( $\mathrm{g} / \mathrm{kg}$ dry body weight) of tissues from rats fed for 30,250 or $700 \mathrm{~d}$ on control diet or diets containing legume-seed meals*

(Mean values for the following numbers of animals: $30 \mathrm{~d}, n 12 ; 250 \mathrm{~d}, n 12 ; 700 \mathrm{~d}, n 15$ except for SOY ( $n$ 11), COWPEA ( $n$ 14) and CONTROL $(n$ 14))

\begin{tabular}{|c|c|c|c|c|c|c|c|}
\hline Diet... & CONTROL & LUPIN & $30 \mathrm{~KB}$ & $90 \mathrm{~KB}$ & SOY & COWPEA & $\begin{array}{c}\text { Pooled } \\
\text { SD }\end{array}$ \\
\hline \multicolumn{8}{|l|}{ Stomach } \\
\hline $30 \mathrm{~d}$ & $2 \cdot 9^{\mathrm{a}}$ & ND & $3 \cdot 0^{\mathrm{a}}$ & $3 \cdot 4^{8}$ & $3 \cdot 1^{a}$ & $3 \cdot 2^{\mathrm{a}}$ & $0-3$ \\
\hline $250 \mathrm{~d}$ & $2 \cdot 0^{\mathrm{a}}$ & $2 \cdot 3^{\mathrm{a}}$ & $2 \cdot 0^{\mathrm{a}}$ & $2 \cdot 3^{a}$ & $2 \cdot 5^{b}$ & $2 \cdot 5^{b}$ & $0 \cdot 2$ \\
\hline $700 \mathrm{~d}$ & $1 \cdot 4^{a}$ & $1 \cdot 8^{\mathrm{a}}$ & $1 \cdot 4^{\mathrm{a}}$ & $1 \cdot 6^{\mathrm{a}}$ & $2 \cdot 3^{b}$ & $2 \cdot 2^{b}$ & 0.3 \\
\hline \multicolumn{8}{|l|}{ Small intestine } \\
\hline $30 \mathrm{~d}$ & $15 \cdot 8^{a}$ & ND & $18 \cdot 9^{b}$ & $24 \cdot 3^{\mathrm{c}}$ & $16 \cdot 6^{\mathrm{a}}$ & $16 \cdot 0^{\mathrm{a}}$ & 0.8 \\
\hline $250 \mathrm{~d}$ & $11 \cdot 2^{\mathrm{a}}$ & $12 \cdot 1^{\mathrm{a}}$ & $12 \cdot 2^{\mathrm{a}}$ & $15 \cdot 2^{b}$ & $12 \cdot 3^{\mathrm{a}}$ & $11 \cdot 7^{\mathrm{a}}$ & $0-8$ \\
\hline $700 \mathrm{~d}$ & $9 \cdot 5^{\mathrm{a}}$ & $10 \cdot 4^{a}$ & $10 \cdot 6^{a}$ & $12 \cdot 3^{b}$ & $10 \cdot 5^{\mathrm{a}}$ & $10 \cdot 6^{\mathrm{a}}$ & $1 \cdot 0$ \\
\hline \multicolumn{8}{|l|}{ Caecum } \\
\hline $30 \mathrm{~d}$ & $2 \cdot 3^{a}$ & ND & $2 \cdot 2^{\mathrm{a}}$ & $2 \cdot 3^{a}$ & $2 \cdot 3^{a}$ & $2 \cdot 3^{\mathrm{a}}$ & $0 \cdot 2$ \\
\hline $250 \mathrm{~d}$ & $1 \cdot 2^{\mathrm{a}}$ & $2 \cdot 0^{\mathrm{b}}$ & $1 \cdot 4^{\mathrm{a}}$ & $1 \cdot 6^{b}$ & $1 \cdot 6^{b}$ & $1 \cdot 6^{b}$ & $0 \cdot 1$ \\
\hline $700 \mathrm{~d}$ & $0.9^{\mathrm{a}}$ & $1 \cdot 5^{\mathrm{b}}$ & $1 \cdot 0^{\mathrm{a}}$ & $1 \cdot 4^{b}$ & $1 \cdot 5^{\mathrm{b}}$ & $1 \cdot 4^{\mathrm{h}}$ & $0 \cdot 2$ \\
\hline \multicolumn{8}{|l|}{ Colon } \\
\hline $30 \mathrm{~d}$ & $3 \cdot 1^{a}$ & ND & $3 \cdot 2^{a}$ & $3 \cdot 4^{2}$ & $3 \cdot 3^{\mathrm{a}}$ & $3 \cdot 3^{a}$ & 0.2 \\
\hline $250 \mathrm{~d}$ & $1 \cdot 7^{\mathrm{a}}$ & $2 \cdot 6^{b}$ & $1 \cdot 6^{\mathrm{a}}$ & $2 \cdot 3^{b}$ & $2 \cdot 6^{b}$ & $2 \cdot 3^{b}$ & $0 \cdot 3$ \\
\hline $700 \mathrm{~d}$ & $1 \cdot 3^{a}$ & $2 \cdot 0^{b}$ & $1 \cdot 4^{a}$ & $1.8^{b}$ & $2 \cdot 1^{b}$ & $1.8^{b}$ & 0.2 \\
\hline \multicolumn{8}{|l|}{ Pancreas } \\
\hline $30 \mathrm{~d}$ & $3 \cdot 1^{a}$ & ND & $3 \cdot 7^{\mathrm{b}}$ & $4 \cdot 7^{c}$ & $4 \cdot 6^{c}$ & $3.7^{b}$ & 0.2 \\
\hline $250 \mathrm{~d}$ & $1 \cdot 8^{\mathrm{a}}$ & $1 \cdot 8^{a}$ & $1 \cdot 7^{\mathrm{a}}$ & $1.9^{\mathrm{a}}$ & $2 \cdot 6^{\mathrm{c}}$ & $2 \cdot 1^{b}$ & $0 \cdot 1$ \\
\hline $700 \mathrm{~d}$ & $1 \cdot 2^{\mathrm{a}}$ & $1 \cdot 4^{\mathrm{a}}$ & $1 \cdot 2^{\mathrm{a}}$ & $1 \cdot 3^{u}$ & $2 \cdot 3^{\mathrm{b}} \ddagger$ & $1.7^{c}+$ & 0.2 \\
\hline \multicolumn{8}{|c|}{ Gastrocnemius muscles $\dagger$} \\
\hline $30 \mathrm{~d}$ & $6 \cdot 9^{\mathrm{a}}$ & ND & $7 \cdot 0^{\mathrm{a}}$ & $7 \cdot 5^{b}$ & $6 \cdot 9^{\mathrm{a}}$ & $7 \cdot 0^{\mathrm{a}}$ & $0 \cdot 2$ \\
\hline $250 \mathrm{~d}$ & $3.9^{\mathrm{a}}$ & $4 \cdot 0^{\mathrm{a}}$ & $4 \cdot 1^{a}$ & $4 \cdot 4^{\mathrm{b}}$ & $4 \cdot 0^{\mathrm{a}}$ & $4 \cdot 1^{2}$ & $0 \cdot 1$ \\
\hline $700 \mathrm{~d}$ & $2 \cdot 9^{\mathrm{a}}$ & $3 \cdot 2^{\mathrm{a}}$ & $3 \cdot 1^{\mathrm{a}}$ & $3 \cdot 8^{\mathrm{b}}$ & $3-1^{a}$ & $3 \cdot 0^{\mathrm{a}}$ & $0 \cdot 2$ \\
\hline
\end{tabular}

LUPIN, lupin-seed (Lupinus angustifolius) meal; 30 KB, $30 \mathrm{~g}$ kidney bean (Phaseolus vulgaris var. Processor)/kg diet; $90 \mathrm{~KB}, 90 \mathrm{~g}$ kidney bean $/ \mathrm{kg}$ diet; SOY, soya-bean (Glycine max) meal; COWPEA, cowpea (Vigna unguiculata) meal; ND, not determined.

$a, b, c$ Values within a row with unlike superscript letters were significantly different $(P \leqslant 0.01)$.

* For details of diets and procedures, see Table 1 and pp. 18-20.

$\dagger$ Combined weight of muscles from both hind-legs.

\$ Limited development of macroscopic pancreatic nodules was evident in four of the SOY group and two of the COWPEA group. These lesions were not apparent in the remainder of these groups or in the other control or test groups.

were similar in extent to those observed in SOY-fed rats, the enlargement of the pancreas tended at all timepoints to be less extensive than that caused by dietary SOY.

Enlargement of the small intestine was observed in rats fed on the $90 \mathrm{~KB}$ diet for 30,250 or $700 \mathrm{~d}$ (Table 4). However, the extent to which the $90 \mathrm{~KB}$ diet induced small-intestine enlargement appeared to reduce with time. Thus, after $30 \mathrm{~d}$ the small intestine of rats given $90 \mathrm{~KB}$ was approximately $53 \%$ heavier than that of controls, whereas it was only $30 \%$ heavier than that of comparable controls after $700 \mathrm{~d}$. This diminution in response with time may possibly explain why small-intestine enlargement was evident in rats fed on a lower concentration of kidney bean $(30 \mathrm{~KB})$ for $30 \mathrm{~d}$ but not in those fed on this diet for 250 or $700 \mathrm{~d}$ (Table 4).

Significant pancreatic enlargement was induced by feeding rats for $30 \mathrm{~d}$ on $30 \mathrm{~KB}$ or $90 \mathrm{~KB}$ (Table 4). However, the effects did not seem to persist. Thus, after 250 or $700 \mathrm{~d}$ no significant pancreatic enlargement was evident in rats fed on these kidney-bean diets.

Gastrocnemius muscles in rats on $90 \mathrm{~KB}$ were considerably reduced in absolute weight. 
Table 5. Dry weights ( $\mathrm{g} / \mathrm{kg}$ dry body weight) of tissues from rats fed on diets containing soya bean (Glycine max SOY 1, SOY 2) or cowpea (Vigna unguiculata) meal (COWPEA) killed during the period $50 \dot{0}-700$ d because they were showing signs of distress, compared with values for soya-bean fed rats (SOY) killed as planned at $700 d^{*}$

\begin{tabular}{|c|c|c|c|c|c|}
\hline Diet... & $\begin{array}{c}\text { COWPEA } \\
(n 1)\end{array}$ & $\begin{array}{l}\text { SOY } 1 \\
(n 4)\end{array}$ & $\begin{array}{l}\text { SOY } 2 \\
(n 8)\end{array}$ & $\begin{array}{l}\text { SOY } \\
(n 6)\end{array}$ & $\begin{array}{l}\text { Pooled } \\
\text { SD }\end{array}$ \\
\hline Small intestine & 8.9 & $8 \cdot 2^{b}$ & $11 \cdot 0^{\mathrm{a}}$ & $10 \cdot 4^{\mathrm{a}}$ & $1 \cdot 1$ \\
\hline Caecum & $1 \cdot 3$ & $1.2^{\mathrm{b}}$ & $1 \cdot 4^{\mathrm{a}}$ & $1 \cdot 5^{\mathrm{a}}$ & 0.2 \\
\hline Colon & 1.6 & $1 \cdot 5^{b}$ & $2 \cdot 1^{\mathrm{a}}$ & $2 \cdot 0^{\mathrm{a}}$ & $0 \cdot 2$ \\
\hline Pancreas & $7.9+$ & $9 \cdot 2^{c}+$ & $5 \cdot 0^{b}+$ & $2 \cdot 4^{\mathrm{a}}$ & $1 \cdot 3$ \\
\hline Spleen & 1.9 & $3 \cdot 0^{\mathrm{b}}$ & $1 \cdot 3^{\mathrm{a}^{+}}$ & $1 \cdot 0^{\mathrm{a}}$ & 0.7 \\
\hline Liver & $14 \cdot 2$ & $16 \cdot 9^{\mathrm{b}}$ & $13 \cdot 9^{\mathrm{a}}$ & $14 \cdot 5^{\mathrm{a}}$ & $1 \cdot 0$ \\
\hline Kidneys & 1.9 & $2 \cdot 6^{\mathrm{b}}$ & $1.9^{\mathrm{a}}$ & $1.8^{\mathrm{a}}$ & 0.3 \\
\hline Gastrocnemius muscles§ & $2 \cdot 6$ & $2 \cdot 0^{\mathrm{b}}$ & $3 \cdot 0^{\mathrm{a}}$ & $3 \cdot 1^{\mathrm{a}}$ & 0.3 \\
\hline
\end{tabular}

${ }^{a, b}$ Values for SOY, SOY 1 and SOY 2 within a row with unlike superscript letters were significantly different $(P \leqslant 001)$.

* For details, see pp. 18-20.

$\uparrow$ Very extensive development of macroscopic pancreatic nodules was evident and there were indications of neoplasia.

$\ddagger$ Very extensive development of macroscopic nodules was evident over the whole pancreas.

$\S$ Combined weight of muscles from both hind-legs.

However, on a proportional basis they constituted a much higher proportion of the total dry body weight than did those of control rats (Table.4). This was consistent with the finding that carcasses of rats fed on $90 \mathrm{~KB}$ had a high percentage of body protein. Longterm consumption of the $30 \mathrm{~KB}$ diet did not significantly alter proportional gastrocnemius weights (Table 4).

Caecum and colon weights were significantly increased in rats fed on $90 \mathrm{~KB}$ for 250 or $700 \mathrm{~d}$ (Table 4). These changes were not observed in rats fed on $30 \mathrm{~KB}$. However, they were apparent in rats fed on LUPIN diet for 250 or $700 \mathrm{~d}$.

Four of the control rats had to be killed between 500 and $700 \mathrm{~d}$ because they were exhibiting signs of acute distress. With three of the rats the urinary bladders were found to be greatly distended and to contain considerable amounts of spherical, white, bladder stones. The kidneys of these rats were also significantly enlarged. The liver of the fourth control rat was found to be 2-3 times larger than normal, it had a yellow mottled appearance and there appeared to be some tumour development in the tissue. The spleen of this rat was also greatly enlarged. Development of urinary bladder stones was not observed in any of the rats fed on legume-based diets. Tissue weights from these four control animals were not included in the Tables.

\section{DISCUSSION}

The soya beans used in the present study contained high levels of trypsin-inhibitory activity and lower levels of chymotrypsin-inhibiting activity. This appeared to be consistent with the seeds containing a combination of Kunitz (trypsin) and Bowman-Birk (trypsin/ chymotrypsin) inhibitors (Pusztai et al. 1991 b). Cowpeas and kidney beans had moderate levels of both trypsin- and chymotrypsin-inhibitory activity which appeared to be consistent with the presence of Bowman-Birk type inhibitors but no Kunitz inhibitors in these seeds (Pusztai, 1966; Norton, 1991). However, lupin seeds contained only very low 
concentrations of trypsin and chymotrypsin inhibitors, as found before (Kim \& Madhusudhan, 1988).

Lectin activity, as expected, was very high in kidney bean, significantly lower in soya bean and very low in cowpea and lupin seed (Pusztai \& Palmer, 1977; Grant et al. 1983; Kim \& Madhusudhan, 1988; Pusztai et al.1991 b).

Inclusion of the legume-seed meals in diets for young rats significantly impaired feed conversion efficiency and growth. However, the growth-reducing effects of dietary legumes appeared to diminish with time and after $200 \mathrm{~d}$ the growth rates of rats on the test diets were close to those of controls given the same daily intake. This could have been due, in part, to adaptation to the diets. However, it is more likely that age-linked changes in metabolism decreased the susceptibility of rats to the effects of the legume-based diets.

Ageing rats $(200 \mathrm{~d}+)$ gain weight very slowly and have lower requirements for dietary nutrients (Rogers, 1979). Therefore, any limitation in nutrient availability or interference with body metabolism caused by the presence of legume-seed meals in the diet would be far less deleterious for them than it would for young, rapidly growing rats. Legume lectins and trypsin inhibitors do interfere with body metabolism and nutrient availability (Grant, 1989; Pusztai, 1991). However, in the present study the levels of lectin and/or protease inhibitors in the test diets were insufficient to stop growth or cause acute toxic effects in young, rapidly growing rats. The interference with intermediary metabolism caused by these antinutritional factors was thus limited in extent. They are therefore liable to have had even less effect on metabolism in ageing rats and this may explain why after $200 \mathrm{~d}$ the growth rates of rats on these diets were similar to those of controls given the same daily feed intake. This would also be consistent with the findings that the weight gains of mature rats or hens were not altered by inclusion of raw soya bean or kidney bean in their diets (Saxena et al. 1963; Booth et al. 1964; Rackis, 1974; Pusztai, 1980).

Net protein and lipid accretion by rats was reduced as a result of inclusion of legumeseed meals in their diet. However, only in the case of the $90 \mathrm{~KB}$ diet (high lectin content, moderate protease inhibitor content) did this result in a change in the composition of the carcass. It seems likely that the reduction in the proportion of carcass lipid was due to the relatively high amount of lectin present in the diet since the other legume diets $(30 \mathrm{~KB}$, moderate lectin content, low protease-inhibitor content; SOY, moderate lectin content, high protease-inhibitor content; COWPEA, moderate trypsin inhibitor levels, low lectin content and LUPIN, low lectin and low protease-inhibitor contents) did not appear to cause this change. Rapid depletion of body lipid and protein and weight loss were previously observed in rats fed on very high levels of dietary kidney bean $(260 \mathrm{~g} / \mathrm{kg}$ diet $)$ or kidney-bean lectins (Pusztai et al. 1986; Grant et al. 1988; Pusztai, 1991).

Dietary lectins are known to survive passage through the gastrointestinal tract, to interact with epithelial cells of the small intestine, to be endocytosed into enterocytes and to be released systemically in an intact and fully reactive form (Pusztai et al. 1989, 1990; Pusztai, 1991). Due to this ability to bind to enterocytes and/or to be taken up systemically, kidney-bean lectins can interfere with hormone balance and in particular with pancreatic insulin synthesis and secretion (Pusztai et al. 1991 a; Carvalho, 1993). At very high dietary kidney-bean lectin intakes this leads to very low circulating insulin levels and appears to cause net catabolism of body lipid and protein (Pusztai et al. 1986, 1991 a; Pusztai 1991; Carvalho, 1993). Lipid depletion occurs more rapidly than does that of muscle/protein and, as a result, the proportion of lipid in the carcass of kidney-bean-lectin-fed rats decreases whilst that of protein increases. There is also apparently a compensatory increase in carcass water (Grant et al. 1988).

Kidney beans or kidney-bean lectins therefore have severe effects on body composition and metabolism when fed to rats at very high dietary levels for up to $10 \mathrm{~d}$ (Pusztai, 1991). 
It was previously shown that at lower levels of dietary inclusion neither kidney beans $(100 \mathrm{~g} / \mathrm{kg}$ diet $)$ nor purified kidney-bean lectins caused any significant changes in body composition when fed to young rats for $10 \mathrm{~d}$ (de Oliveira, 1986; de Oliveira et al. 1988). However, the findings of the present study suggest that even at these lower levels of dietary inclusion kidney bean interfered with lipid and protein accretion and could cause small but significant changes in body composition in the longer term. Indeed, the rate of lipid deposition by rats fed on the $90 \mathrm{~KB}$ diet appeared to be reduced throughout the $700 \mathrm{~d}$ trial period whereas protein accretion appeared to be lowered primarily during the rapid growth phase of the rats. Furthermore, the potentially beneficial lowering of percentage body lipid observed in rats fed on $90 \mathrm{~KB}$ was achieved in the absence of the acute toxicity effects, such as rapid weight loss, observed in rats fed on very high levels of kidney bean (Pusztai, 1989, 1991).

Small-intestine enlargement was evident after long-term exposure of rats to the $90 \mathrm{~KB}$ diet. However, the extent of the small-intestine enlargement, which is due specifically to the trophic effects of the constituent seed lectin (Pusztai, 1989, 1991), was no greater than that found in rats given this diet for $30 \mathrm{~d}$. Indeed, there were some indications that the changes occurred to a lesser extent in the older rats. Therefore, although the trophic effects of comparatively low dietary levels of kidney bean towards the small intestine persist in the long term, they are probably not cumulative.

Dietary kidney bean ( 30 or $90 \mathrm{~g} / \mathrm{kg}$ ) appeared to have little or no long-term deleterious effects upon the pancreas. Thus, although pancreatic enlargement occurred in rats given the $90 \mathrm{~KB}$ diet for $30 \mathrm{~d}$, it was not evident after 250 or $700 \mathrm{~d}$. Pancreatic enlargement induced in rats by short-term exposure to dietary kidney bean is due primarily to the presence of the constituent seed lectins (de Oliveira et al. 1988; Pusztai, 1989). The present study indicated that long-term dietary exposure to low levels of kidney bean had no cumulative deleterious effects on pancreatic metabolism. The reasons for the diminution in the trophic effects of dietary lectin on the pancreas remain unknown but are possibly linked to agerelated changes in pancreatic and small-intestine structure and function (Vellas et al. 1990).

Soya-bean and cowpea diets, as expected, caused rapid pancreatic growth in rats. The pancreatic enlargement in rats fed on these diets, as noted in other studies with soya bean (McGuiness et al. 1984; Gumbmann et al. 1985, 1989; Grant, 1989, 1990), persisted through to $700 \mathrm{~d}$. Indeed, with rats fed on soya bean or cowpea the enlargement appeared to be far more extensive at $700 \mathrm{~d}$ than that observed at 30 or $250 \mathrm{~d}$. Thus, the trophic effects of dietary soya bean (high Kunitz inhibitor content, moderate Bowman-Birk inhibitor content and moderate lectin content) or cowpea (no Kunitz inhibitor content, moderate Bowman-Birk inhibitor content and low lectin content) on the pancreas persisted on longterm feeding and were possibly cumulative.

Pancreatic enlargement in SOY-fed rats which had to be killed between 500 and $700 \mathrm{~d}$ was much more extensive than that found in those SOY-fed rats which survived the full $700 \mathrm{~d}$ experimental period. Pancreatic samples from these rats showed extensive development of macroscopic pancreatic nodules (McGuiness et al. 1980; Longnecker, 1989) over the whole of tissue. With four of the SOY-fed rats the appearance of the tissue and the presence of adhesions to other tissues suggested that pancreatic neoplasia may have occurred. Splenomegaly, liver and kidney enlargement, and reduced gastrocnemius muscle, small intestine, caecum and colon weights were also evident in these four rats. Similar changes were observed with one rat fed long-term with the cowpea-based diet.

The caecum and colon of rats fed on the SOY, $90 \mathrm{~KB}$, COWPEA or LUPIN diets longterm were enlarged. The reasons for these changes are unknown. However, it did not appear that the lectins or the protease inhibitors were major factors in mediating these changes since diets containing high or low levels of these antinutritional factors were 
equally effective in causing enlargement of the large intestine. It is possible that these changes are linked to production of volatile fatty acids in the caecum as a result of digestion of dietary fibre derived from legume-seed meals (Mathers et al. 1993).

This work was supported by the Scottish Office Agriculture and Fisheries Department.

\section{REFERENCES}

Booth, A. N., Robbins, W. E., Ribelin, W. E., de Eds, F., Smith, A. K. \& Rackis, J. J. (1964). Prolonged pancreatic hypertrophy and reversibility in rats fed raw soybean meal. Proceedings of the Society for Experimental Biology and Medicine 116, 1067-1069.

Carvalho, A. de F. F. U. (1993). Dietary kidney bean lectins affect insulin levels, change gene expression and modulate metabolism. PhD Thesis, University of Aberdeen.

Chase, T. \& Shaw, E. (1967), p-Nitrophenyl- $p^{\prime}$-guanidinobenzoate $\mathrm{HCl}$ : a new active site titrant for trypsin. Biochemical and Biophysical Research Communications 29, 508-514.

Davidson, J., Mathieson, J. \& Boyne, A. W. (1970). The use of automation in determining nitrogen by the kjeldahl method with final calculations by computer. Analyst 95, 181-193.

de Oliveira, J. T. A. (1986). Seed lectins - the effects of dietary (Phaseolus vulgaris) lectins on general metabolism of monogastric animals. PhD Thesis, University of Aberdeen.

de Oliveira, J. T. A., Grant, G. \& Pusztai, A. (1988). Changes in organs and tissues induced by feeding of purified kidney bean (Phaseolus vulgaris) lectins. Nutrition Research 8, 943-947.

Erlanger, F. B., Cooper, A. J. \& Bendich, A. J. (1964). On the heterogeneity of three-times crystallised $\alpha-$ chymotrypsin. Biochemistry 3, 1880-1883.

Grant, G. (1989). Anti-nutritional effects of soyabean: a review. Progress in Food and Nutrition Science 13, 317-348.

Grant, G. (1990). Effects of long-term (2 year) feeding of rats with raw soya bean. Proceedings of the Nutrition Society 49, 143A.

Grant, G. (1991). Lectins. In Toxic Substances in Crop Plants, pp. 49-67 [J. P. F. D'Mello, C. M. Duffus and J. H. Duffus, editors]. Cambridge: Royal Society of Chemistry.

Grant, G., de Oliveira, J. T. A., Dorward, P. M., Annand, M. G., Waldron, M. \& Pusztai, A. (1988). Metabolic and hormonal changes in rats resulting from consumption of kidney bean (Phaseolus vulgaris) or soyabean (Glycine max). Nutrition Reports International 36, 763-772.

Grant, G., Dorward, P. M. \& Pusztai, A. (1993). Pancreatic enlargement is evident in rats fed diets containing raw soybeans (Glycine max) or cowpeas (Vigna unguiculata) for 800 days but not in those fed diets based on kidney beans (Phaseolus vulgaris) or lupinseed (Lupinus angustifolius). Journal of Nutrition 123, 2207-2215.

Grant, G., Ewen, S. W. B., Bardocz, S., Brown, D. S., Dorward, P. M., Watt, W. B., Stewart, J. C. \& Pusztai, A. (1989). Local (gut) and systemic response of rats to dietary soyabean (Glycine max) proteins. In Recent Advances of Research in Antinutritional Factors in Legume Seeds, pp. 34-38 [J. Huisman, T. F. B. van der Poel and I. E. Liener, editors]. Wageningen: Pudoc.

Grant, G., McKenzie, N. H., Watt, W. B., Stewart, J. C., Dorward, P. M. \& Pusztai, A. (1986). Nutritional evaluation of soya beans (Glycine max): nitrogen balance and fractionation studies. Journal of the Science of Food and Agriculture 37, 1001-1010.

Grant, G., More, L. J., McKenzie, N. H., Stewart, J. C. \& Pusztai, A. (1983). A survey of the nutritional and haemagglutinating properties of legume seeds generally available in the UK. British Journal of Nutrition $\mathbf{5 0}$, 207-214.

Grant, G., Watt, W. B., Stewart, J. C. \& Pusztai, A. (1987a). Effects of dietary soyabean (Glycine max) lectin and trypsin inhibitors upon the pancreas of rats. Medical Science Research 15, 1197-1198.

Grant, G., Watt, W. B., Stewart, J. C. \& Pusztai, A. (1987b). Changes in the small intestine and hind-leg muscle of rats induced by dietary soyabean (Glycine max) proteins. Medical Science Research 15, 1355-1356.

Gumbmann, M. R., Dugan, G. M., Spangler, W. L., Baker, E. C. \& Rakis, J. J. (1989). Pancreatic response in rats and mice to trypsin inhibitors from soy and potato after short- and long-term dietary exposure. Journal of Nutrition 119, 1589-1609.

Gumbmann, M. R., Spangler, W. L., Dugan, G. M., Rackis, J. J. \& Liener, I. E. (1985). The USDA trypsin inhibitor study. IV. The chronic effects of soy flour and soy protein isolate on the pancreas of rats after two years. Qualitas Plantarum. Plant Foods for Human Nutrition 35, 275-314.

Kakade, M. L., Simons, N. \& Liener, I. E. (1969). An evaluation of natural vs synthetic substrates for measuring the antitryptic activity of soyabean samples. Cereal Chemistry 46, 518-526.

Kim, C. S. \& Madhusudhan, K. T. (1988). Haemagglutinating and trypsin inhibitor activities of lupin seeds (Lupinus angustifolius). Journal of the Science of Food and Agriculture 53, 1234-1235.

Liener, I. E. (editor) (1980). Toxic Constituents of Plant Foodstuffs. New York: Academic Press.

Liener, I. E. (1989). Control of antinutritional and toxic factors in oilseeds and legumes. In Food Uses of Whole Oil and Protein Seeds, pp. 344-371 [E. W. Lusas, D. R. Erickson and W. Nip, editors]. Illinois: American Oil Chemists Society. 
Longnecker, D. S. (1989). Experimental pancreatic carcinogenesis. Current Opinion in Gastroenterology 5, 723-727.

McGuiness, E. E., Morgan, R. G. H., Levison, D. A., Frape, D. L., Hopwood, D. \& Wormsley, K. G. (1980). The effects of long-term feeding of soya flour upon the rat pancreas. Scandinavian Journal of Gastroenterology $\mathbf{1 5}$, 497-502.

McGuiness, E. E., Morgan, R. G. H. \& Wormsley, K. G. (1984). Effects of soyabean flour upon the pancreas of rats. Environmental Health Perspectives 56, 205-212.

Mathers, J. C., Kennard, J. \& James, O. F. W. (1993). Gastrointestinal responses to oats consumption in young and elderly rats: digestion, large bowel fermentation and crypt cell proliferation rates. British Journal of Nutrition 70, 567-584.

Norton, G. (1991). Proteinase inhibitors. In Toxic Substances in Crop Plants, pp. 68-106 [J. P. F. D'Mello, C. M. Duffus and J. H. Duffus, editors]. Cambridge: Royal Society of Chemistry.

Pusztai, A. (1966). The isolation of two proteins, glycoprotein I and a trypsin inhibitor, from the seeds of kidney bean (Phaseolus vulgaris). Biochemical Journal 101, 379-384.

Pusztai, A. (1980). Nutritional toxicity of kidney bean (Phaseolus vulgaris). Report of the Rowett Research Institute 36, 110-118.

Pusztai, A. (1989). Biological effects of dietary lectins. In Recent Advances of Research in Antinutritional Factors in Legume Seeds, pp. 17-29 [J. Huisman, T. F. B. van der Poel \& I. E. Liener, editors]. Wageningen: Pudoc.

Pusztai, A. (editor) (1991). Plant Lectirs. Cambridge: Cambridge University Press.

Pusztai, A., Ewen, S. W. B., Carvalho, A. de F. F. U., Grant, G., Stewart, J. C. \& Bardocz, S. (1991 a). Immune and hormonal effects of dietary lectins. In European Food Toxicology. III. Proceedings of the Interdisciplinary Conference on Effects of Food on the Immune and Hormonal Systems, pp. 20-24. Zurich, Switzerland: University of Zurich.

Pusztai, A., Ewen, S. W. B., Grant, G., Peumans, W. P., van Damme, E. J. M., Rubio, L. \& Bardocz, S. (1990). Relationship between survival and binding of plant lectins during small intestinal passage and their effectiveness as growth factors. Digestion 46, Suppl., 308-316.

Pusztai, A., Grant, G., Brown, D. J., Stewart, J. C., Bardocz, S., Ewen, S. W. B., Gatehouse, A. M. R. \& Hilder, V. (1992). Nutritional evaluation of the trypsin (EC 3.4.21.4) inhibitor from cowpea (Vigna unguiculata Walp.). British Journal of Nutrition 68, 783-791.

Pusztai, A., Grant, G. \& de Oliveira, J. T. A. (1986). Local (gut) and systemic responses to dietary lectins. IRCS Medical Science 14, 205-208.

Pusztai, A., Greer, F. \& Grant, G. (1989). Specific uptake of dietary lectins into the systemic circulation of rats. Biochemical Society Transactions 17, 481-482.

Pusztai, A. \& Palmer, R. (1977). Nutritional evaluation of the kidney beans (Phaseolus vulgaris): the toxic principle. Journal of the Science of Food and Agriculture 28, 620-623.

Pusztai, A., Watt, W. B. \& Stewart, J. C. $(1991 b)$. A comprehensive scheme for the isolation of trypsin inhibitors and the agglutinin from soyabean seeds. Journal of Agricultural and Food Chemistry 39, 862-866.

Rackis, J. J. (1974). Biological and physiological factors in soyabeans. Journal of the American Oil Chemists Society 51, 161A-174A.

Rogers, A. E. (1979). Nutrition. In The Laboratory Rat. Vol. 1. Biology and Diseases, pp. 123-152 [H. J. Baker, J. R. Linsdsey and S. H. Weisbroth, editors]. New York: Academic Press.

Saxena, H. C., Jensen, L. S. \& McGinnis, J. (1963). Influence of age on the utilization of soybean meal by chickens. Journal of Nutrition 80, 391-396.

Schonbaum, G. R., Zerner, B. \& Bender, M. L. (1961). The spectrophotometric determination of the operational normality of an $\alpha$-chymotrypsin solution. Journal of Biological Chemistry 236, 2930-2935.

Vellas, B. J., Balas, D., Lafont, C., Senegas-Balas, F., Albarede, J. \& Ribet, A. (1990). Adaptive response of pancreatic and intestinal function to nutritional intake in the aged. Journal of the American Geriatric Society 38, 254-258.

Zar, J. H. (editor) (1984). Biostatistical Analysis. Englewood Cliffs, NJ : Prentice-Hall Inc. 